\title{
Vasculature pattern of the petals of the species Kallstroemia pubescens, which indicates the evolutionary status of this taxa
}

\author{
Bidyut Kumar Jana and Sobhan Kumar Mukherjee
}

University of Kalyani, Kalyani 741235, Nadia, West Bengal, India

\section{Article history}

Received: 8 October 2015

Accepted: 3 November 2015

Published online: 1 January 2016

(C) Jana and Mukherjee (2016)

Editor

K. K. Sabu

\section{Publisher}

Horizon e-Publishing Group

Corresponding Author

Bidyut Kumar Jana

$凶$ janabotanytaxonomy@gmail.com

\begin{abstract}
This paper deals with the details variation of petal venation in Kallstroemia pubescens of the family Zygophyllaceae. In the present study, from a pool of 100 petals, 40 petals were selected randomly to observe the variation of venation patterns of petals in different flowers of same species collected from different population of the same ecological area. All the 40 petals examined, as per Foster's classification, shows various type of anastomoses. Detailed study reveals that after the entry of a single vain in a petal, it divided into two costals and one median. Actually anastomosis takes place between the sister's branches of the costal or between a branch of the costal and a branch of the medion. Present observation on the anastomosis of the petal venation of the $K$. pubescens is clearly fits with the study of Foster (1968). At the basal region of petal, Type-I(35.2\%) and Type-II(35.2\%) are more prevalent, than Type-III (5.8\%), Type-VI (5.8\%) and Type-V (17.5\%).At the middle region of petal, Type-II (47.56\%) is more prevalent than Type-I (17.07\%), Type-V (13.41\%), Type-III (13.41\%), Type-IV (4.8\%) and Type-VI (3.65\%). At the distal region, Type-II (44.7\%) is more prevalent than Type-III (33.33\%), Type-I (10.41\%), Type-V (8.33 \%), Type-VI (2.08 \%) and Type-IV (1.04 \%).
\end{abstract}

Keywords

Petal venation; Kallstroemia pubescens; Zygophyllaceae

Jana, B. K. and Mukherjee, S. K. 2016. Vasculature pattern of the petals of the species Kallstroemia pubescens, which indicates the evolutionary status of this taxa. Plant Science Today 3(1): 19-24. http://dx.doi.org/10.14719/pst.2016.3.1.169

\section{Introduction}

The vasculature pattern of petal is commonly known as petal venation. The study of petal venation received the attention of many workers in different times in tracing phylogeny after the remark that petal venation shows diversity (Melville, 1969; Banerjie, 1976; Arnott and Tucker, 1963).Petal venation of irregular flower has been carried many workers (Datta and Saha, 1968; Subramanyam and Nair, 1973; Gupta, 1982), whereas petal venation of regular corolla has been documented by many other workers (Arnott\& Tucker, 1963; Banerji and Mukherjee,1970; Banerji 1972, 1976 etc.). Regarding the venation pattern of petal, Foster (1966), put forward the ideas of petal architecture, which is usually with open dichotomous or weakly reticulate vasculature that may provide some information to the evolutionary development of venation pattern in the Angiosperm. Melville (1969), Foster (1971), Banerjie (1976), Jana and Mukherjee (2013) and Jana, Saha and Mukherjee (2013), have done some contribution regarding the petal venation in different taxa of Angiosperms. Literature about the study of petal venation is remarkably meager. Some of the workers have studied the petal venation of some taxa (Chetek, 1962, 1963; Arnott and Tucker, 1963; Datta and Saha, 1968; Banerji and 
Table 1. Showing the number of dichotomies and anastomoses in studied petals of Kallstroemia pubescens

\begin{tabular}{|c|c|c|c|c|c|c|c|c|}
\hline $\begin{array}{c}\text { Figure } \\
\text { No. }\end{array}$ & $\begin{array}{l}\text { Number } \\
\text { of } \\
\text { Dichotom } \\
\text { ies at } \\
\text { basal } \\
\text { region }\end{array}$ & $\begin{array}{l}\text { Number } \\
\text { of } \\
\text { Dichotom } \\
\text { ies at } \\
\text { central } \\
\text { region }\end{array}$ & $\begin{array}{l}\text { Number of } \\
\text { Dichotomi } \\
\text { es at Distal } \\
\text { region }\end{array}$ & $\begin{array}{l}\text { Total number of } \\
\text { dichotomies in in } \\
\text { each petal }\end{array}$ & $\begin{array}{l}\text { Number } \\
\text { of } \\
\text { anastomo } \\
\text { sis in } \\
\text { basal } \\
\text { region }\end{array}$ & $\begin{array}{l}\text { Number of } \\
\text { anastomos } \\
\text { is in } \\
\text { central } \\
\text { region }\end{array}$ & $\begin{array}{l}\text { Number of } \\
\text { anastomosis } \\
\text { in distal } \\
\text { region }\end{array}$ & $\begin{array}{l}\text { Total number of } \\
\text { anastomosis in in each } \\
\text { petal }\end{array}$ \\
\hline 1 & 13 & 12 & 20 & 45 & 2 & 3 & 6 & 11 \\
\hline 2 & 9 & 11 & 8 & 28 & 2 & 3 & 10 & 15 \\
\hline 3 & 5 & 8 & 16 & 29 & 1 & 3 & 6 & \\
\hline 4 & 7 & 11 & 28 & 46 & 2 & 5 & 12 & 19 \\
\hline 5 & 13 & 16 & 13 & 42 & 0 & 13 & 8 & 21 \\
\hline 6 & 14 & 15 & 14 & 43 & 2 & 7 & 9 & 18 \\
\hline 7 & 21 & 18 & 28 & 67 & 5 & 3 & 19 & 27 \\
\hline 8 & 3 & 11 & 16 & 31 & 0 & 0 & 10 & 10 \\
\hline 9 & 8 & 15 & 14 & 37 & 0 & 5 & 8 & 13 \\
\hline 10 & 9 & 6 & 16 & 31 & 2 & 1 & 5 & 8 \\
\hline 11 & 9 & 10 & 13 & 32 & 0 & 2 & 7 & 9 \\
\hline 12 & 10 & 11 & 16 & 38 & 1 & 2 & 12 & 15 \\
\hline 13 & 9 & 18 & 25 & 52 & 1 & 3 & 9 & 13 \\
\hline 14 & 17 & 20 & 17 & 54 & 1 & 3 & 11 & 15 \\
\hline 15 & 16 & 23 & 20 & 59 & 1 & 12 & 13 & 26 \\
\hline 16 & 5 & 18 & 19 & 42 & 0 & 6 & 13 & 19 \\
\hline 17 & 8 & 15 & 20 & 43 & 0 & 4 & 13 & 17 \\
\hline 18 & 13 & 13 & 17 & 43 & 1 & 10 & 14 & 25 \\
\hline 19 & 7 & 12 & 16 & 35 & 0 & 2 & 12 & 14 \\
\hline 20 & 9 & 12 & 12 & 33 & 0 & 4 & 7 & 11 \\
\hline 21 & 3 & 11 & 20 & 34 & 1 & 2 & 13 & 16 \\
\hline 22 & 7 & 12 & 16 & 37 & 0 & 2 & 14 & 16 \\
\hline 23 & 9 & 15 & 20 & 44 & 1 & 6 & 16 & 23 \\
\hline 24 & 11 & 15 & 13 & 39 & 2 & 4 & 15 & 21 \\
\hline 25 & 9 & 12 & 15 & 36 & 1 & 9 & 13 & 23 \\
\hline 26 & 11 & 13 & 15 & 39 & 5 & 1 & 13 & 19 \\
\hline 27 & 13 & 9 & 21 & 43 & 2 & 9 & 12 & 23 \\
\hline 28 & 10 & 13 & 16 & 39 & 0 & 5 & 15 & 20 \\
\hline 29 & 11 & 8 & 15 & 34 & 0 & 2 & 7 & 9 \\
\hline 30 & 9 & 15 & 20 & 44 & 1 & 5 & 10 & 16 \\
\hline 31 & 9 & 15 & 16 & 40 & 0 & 3 & 9 & 12 \\
\hline 32 & 8 & 7 & 11 & 26 & 0 & 3 & 12 & 15 \\
\hline 33 & 10 & 8 & 10 & 28 & 1 & 5 & 6 & 12 \\
\hline 34 & 6 & 14 & 11 & 31 & 0 & 5 & 7 & 12 \\
\hline 35 & 6 & 17 & 21 & 44 & 0 & 7 & 12 & 19 \\
\hline 36 & 6 & 7 & 16 & 29 & 0 & 3 & 10 & 13 \\
\hline 37 & 6 & 8 & 13 & 27 & 0 & 1 & 9 & 10 \\
\hline 38 & 3 & 10 & 7 & 20 & 0 & 3 & 9 & 12 \\
\hline 39 & 6 & 8 & 13 & 27 & 0 & 7 & 14 & 21 \\
\hline 40 & 5 & 11 & 13 & 29 & 0 & 4 & 9 & 13 \\
\hline
\end{tabular}


Table 2. Showing the types of anastomosis in studied petals of Kallstroemia pubescens

\begin{tabular}{|c|c|c|c|c|c|c|}
\hline Figure & $\begin{array}{l}\text { Types of anastomosis } \\
\text { at basal region }\end{array}$ & Total & $\begin{array}{l}\text { Types of anastomosis } \\
\text { at central region }\end{array}$ & Total & $\begin{array}{l}\text { Types of anastomosis } \\
\text { at upper region }\end{array}$ & Total \\
\hline 1 & 0 & & Type.II-1, Type.III-1 & 2 & Type.III-1 & 1 \\
\hline 2 & Type.III-1 & 1 & Type.I-2 & 2 & Type.III-2 & 2 \\
\hline 3 & Type.II-1 & 1 & Type.II-1, Type.V-1 & 2 & Type.III-1 & 1 \\
\hline 4 & 0 & & Type.III-1, Type.V-1 & 2 & Type.III-2, Type.II-3, Type.I-1. & 6 \\
\hline 5 & 0 & & Type.III-2, Type.II-1, Type.V- & 4 & 0 & \\
\hline 6 & Type.II-2, Type.I-1 & 3 & Type.II-2 & 2 & Type.II-2 & 2 \\
\hline 7 & Type.II-3, Type.I-1 & 4 & Type.I-1, Type.II-1, Type.III-1 & 3 & Type.III-2, Type.I-1, Type.II-1 & 4 \\
\hline 8 & 0 & & 0 & & Type.III-1 & 1 \\
\hline 9 & 0 & & Type.I-2, Type. V-1 & 3 & 0 & \\
\hline 10 & 0 & & Type.I-1, Type.II-1 & 2 & Type.III-1 & 1 \\
\hline 11 & Type.V-1 & 1 & Type.II-1 & 1 & Type.II-3 & 3 \\
\hline 12 & 0 & & Type.V-1 & 1 & Type.II-3, Type.III-2 & 5 \\
\hline 13 & Type.I-1 & 1 & Type.I-1, Type.II-1 & 2 & Type.V-1, Type.VI-1 & 2 \\
\hline 14 & Type.I-1 & 1 & Type.II-1 & 1 & 0 & \\
\hline 15 & $\begin{array}{l}\text { Type.I-1, Type.V-1, } \\
\text { Type.VI-1 }\end{array}$ & 3 & $\begin{array}{c}\text { Type.II-3, Type.III-1,Type.IV- } \\
\text { 1, Type.I-1 }\end{array}$ & 6 & Type.II-1, Type.VI-1, Type.V-1 & 3 \\
\hline 16 & 0 & & $\begin{array}{c}\text { Type.I-1, Type.III-1, Type.VI- } \\
1\end{array}$ & 3 & Type.II-1, Type.I-2 & 3 \\
\hline 17 & 0 & & Type.II-1 & 1 & $\begin{array}{l}\text { Type.II-2, Type.III-1, Type.I-1, } \\
\text { Type.V-1 }\end{array}$ & 5 \\
\hline 18 & Type.V-1 & 1 & $\begin{array}{c}\text { Type.II-2, Type.III-1, } \\
\text { Type.I-1, } \\
\text { Type.V-1 }\end{array}$ & 5 & Type.III-1 & 1 \\
\hline 19 & 0 & & 0 & & Type.II-3, Type.III-1 & 4 \\
\hline 20 & 0 & & Type.I-2, Type.II-2 & 4 & Type.III-2 & 2 \\
\hline 21 & 0 & & 0 & & Type.II-1, Type. V-1 & 2 \\
\hline 22 & 0 & & Type.II-1 & 1 & Type.II-1, Type.III-1 & 2 \\
\hline 23 & 0 & & Type.II-2, Type.III-3 & 5 & Type.I-1, Type.II-2, Type.III-3 & 6 \\
\hline 24 & 0 & & Type.II-1, Type.V-1 & 2 & Type.II-2, Type.III-1 & 3 \\
\hline 25 & 0 & & Type.II-2, Type.V-1 & 3 & Type.III-1, Type.II-1 & 2 \\
\hline 26 & 0 & & Type.I-1 & 1 & Type.II-4 & 4 \\
\hline 27 & Type.I-1 & 1 & 0 & & Type.II-1, Type.V-1 & 2 \\
\hline 28 & 0 & & Type.II-2 & 2 & Type.II-1 & 1 \\
\hline 29 & 0 & & Type.II-1 & 1 & Type.III-2, Type.I-1 & 3 \\
\hline 30 & 0 & & Type.II-2 & 2 & Type.III-2 & 2 \\
\hline 31 & 0 & & Type.II-1, Type.IV-2 & 3 & Type.III-2, Type.I-1 & 3 \\
\hline 32 & 0 & & Type.II-1 & 1 & Type.I-1, Type.II-1, Type.III-1 & 3 \\
\hline 33 & 0 & & $\begin{array}{l}\text { Type.II-1, Type.V-1, } \\
\text { Type.VI-1. }\end{array}$ & 3 & 0 & \\
\hline 34 & 0 & & Type.V-2, Type.II-1 & 3 & Type.II-1, Type.V-1 & 2 \\
\hline 35 & 0 & & $\begin{array}{c}\text { Type.I-1, Type.II-1, Type.IV- } \\
\text { 1, Type.VI-1. }\end{array}$ & 4 & Type.II-2 & 2 \\
\hline 36 & 0 & & Type.II-1 & 1 & Type.II-3 & 3 \\
\hline 37 & 0 & & 0 & & Type.II-2, Type.IV-1, Type.V-1 & 4 \\
\hline 38 & 0 & & Type.II-1 & 1 & Type.II-1 & 1 \\
\hline 39 & 0 & & Type.II-1 & 1 & Type.I-1, & 1 \\
\hline 40 & 0 & & Type.II-2 & 2 & Type.III-2, Type.II-1, Type.V-1 & 4 \\
\hline $\begin{array}{c}\text { Total } \\
\text { Anastomoses } \\
\text { in basal region }\end{array}$ & & 17 & $\begin{array}{l}\text { Total } \\
\text { Anastomoses in central } \\
\text { region }\end{array}$ & 82 & $\begin{array}{l}\text { Total } \\
\text { Anastomoses in distal region }\end{array}$ & 96 \\
\hline
\end{tabular}




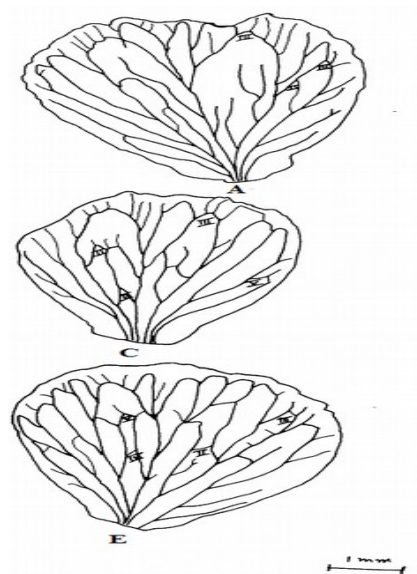

Fig. 1: (A-F). Petal venation of Kallstroemia pubescens
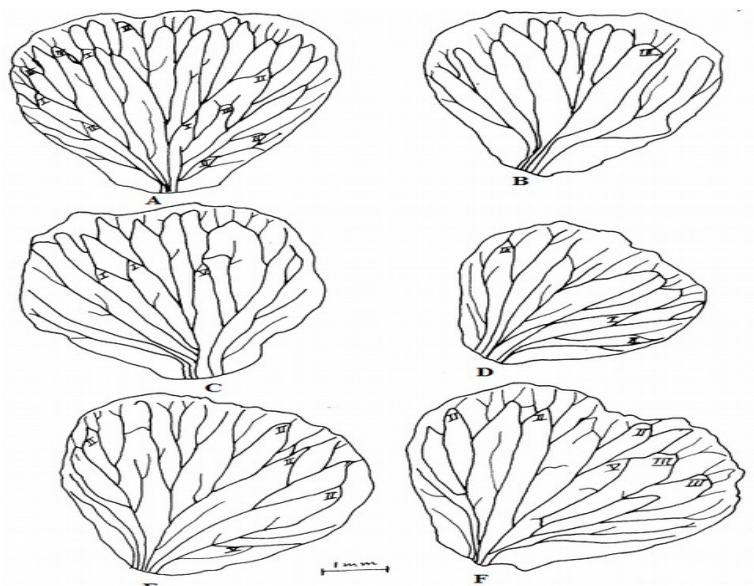

Fig. 2: (A-F). Petal venation of Kallstroemia pubescens
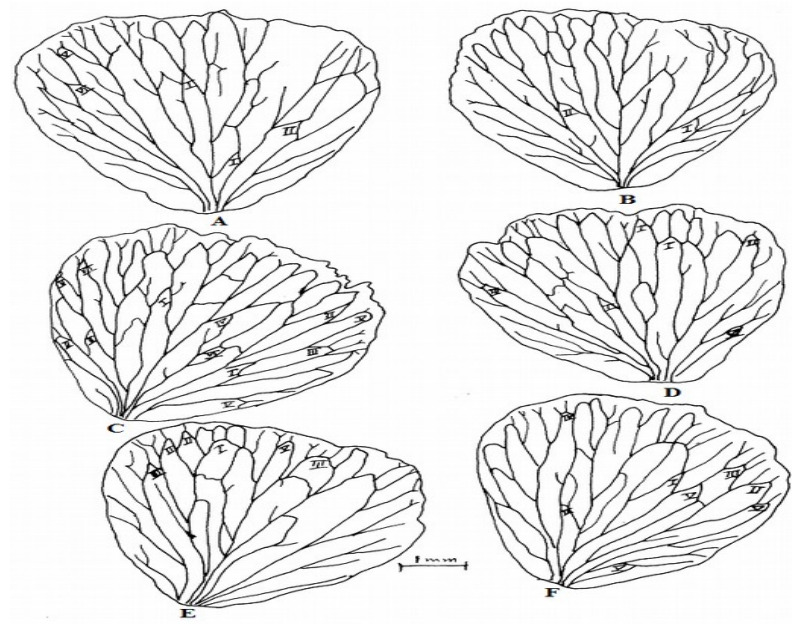

Fig. 3: (A-F). Petal venation of Kallstroemia pubescens
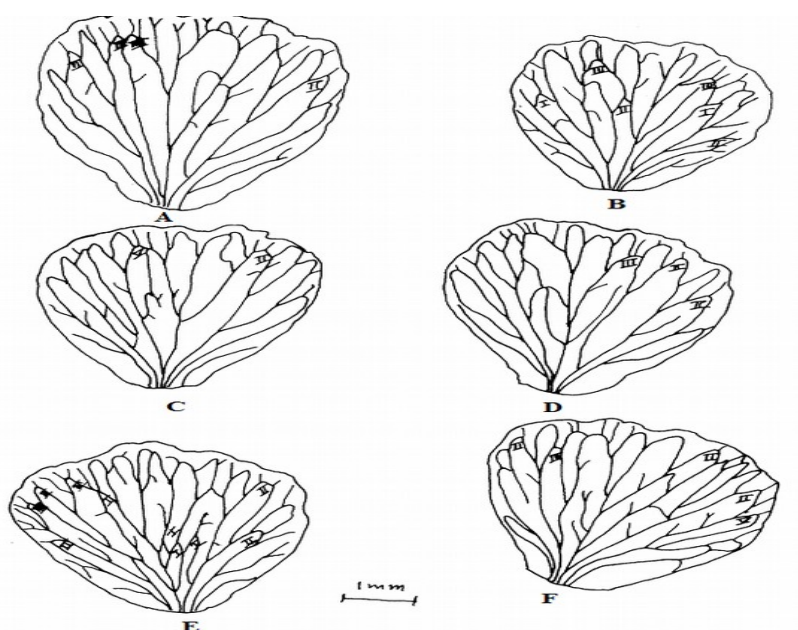

Fig. 4: (A-F). Petal venation of Kallstroemia pubescens
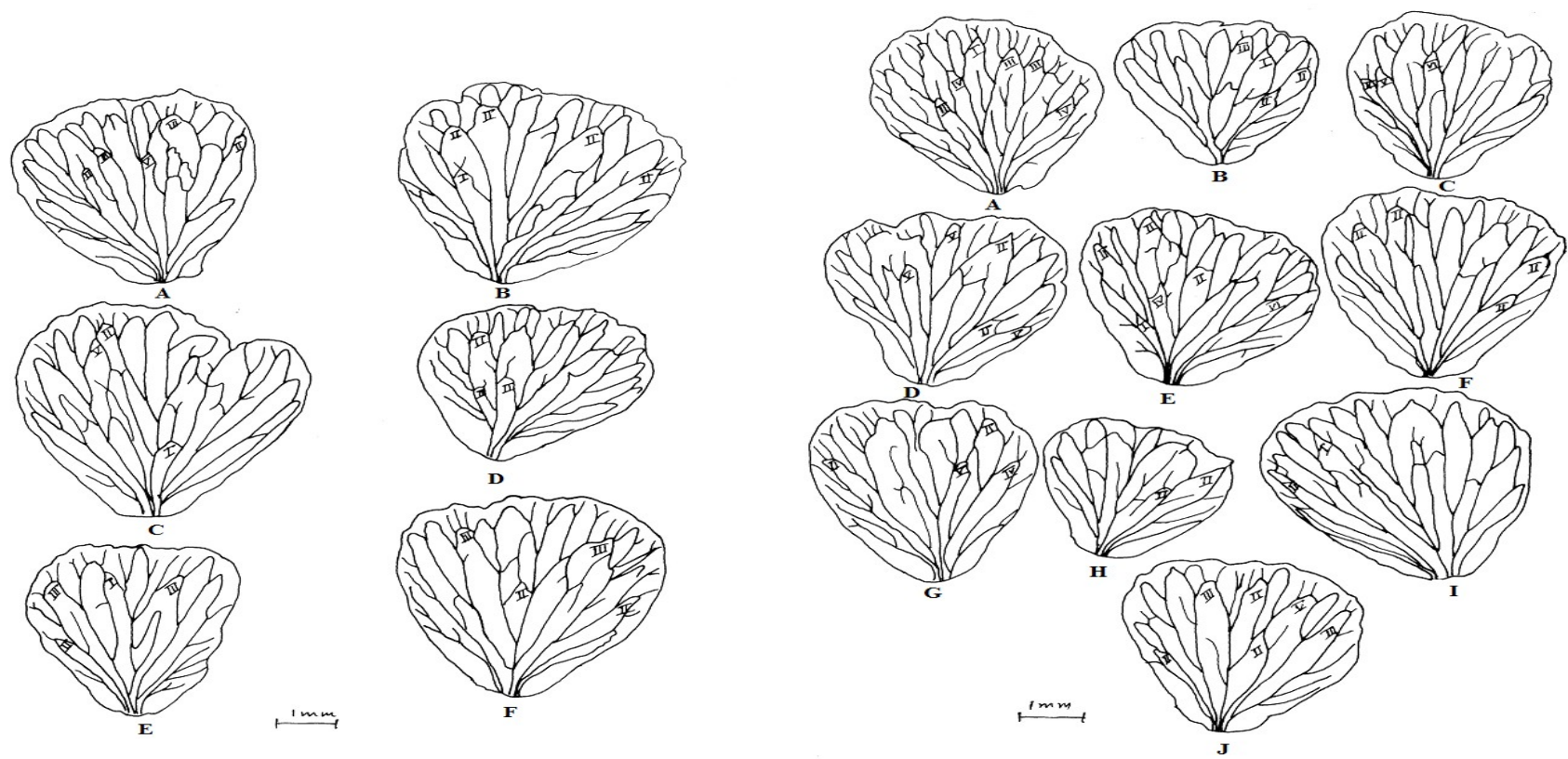

Fig. 6: (A-J). Petal venation of Kallstroemia pubescens 
Mukherjee, 1970). But there are few works on the study of petal venation, therefore; the study of petal venation of $K$. pubescens (G. Don) Dandy, has been under taken. The randomly selected forty petals out of 100 petals from different plants of the same species of $K$. pubescens, have been taken for this study. The perusal of available literature revealed that venation of petals is especially significant at the species level. The genus has 17 species throughout the world and is usually present in Tropical and Worm America (Mabberley, 2008) and also in USA, Costa Rica, Jamaica, Peru, Colombia, Venezuela, India etc. This taxa has not been included in the "Flora of British India", by Hooker, (1875-1897) as well as in "Bengal Plants" (Prain, 1903), but has been included in some district floras of West Bengal (Bennet, 1979), Guha Bakshi (1984), Sanyal (1994), Mitra and Mukherjee (2013). The aims of this study is to show the vasculature pattern of the petals of the species $K$. pubescens, which indicates the evolutionary status of this taxa.

\section{Materials and Methods}

The plant specimens (Fresh petals of K. pubescens) were collected from naturalized populations of Nadia district particularly from Kalyani University campus. Flowers were studied under simple dissecting microscope. Details of the description of each petal has been taken; figures were drawn with the help of prism type of Camera Lucida.

\section{Discussion and Conclusion}

The detailed information regarding the venation pattern of each petal (Fig. 1-6), is given in the table1 and II. The following observations were based on the study of forty petals.

All petals are usually shortly clawed, having many traces, usually obovate in shape with retuse apex. For the study of number of dichotomies and number of anastomoses and type of anastomoses, the petal area has been divided into three sectors, such as basal, middle and upper sector. This division is helpful for the classification of the veins of petals. On the basis of types of anastomoses by Foster (1966-1968), the present studied petals have been classified in to I to VI types. At the basal region of petal, Type-IV type of anastomoses is absent, whereas in middle and distal region of petals, all the VI type of anastomoses are present. It is also evident from the present study that out of VI type of anastomoses of petal veins by Foster $(1966,1968)$, at the basal region of petal, TypeI(35.2\%) and Type-II (35.2\%) are more prevalent, than Type-III(5.8\%), Type-VI (5.8\%) and Type-V (17.5\%).At the middle region of petal, Type-II $(47.56 \%)$ is more prevalent than Type-I (17.07\%), Type-V (13.41\%), Type-III (13.41\%), Type-IV (4.8\%) and Type-VI (3.65\%). At the distal region, Type-II $(44.7 \%)$ is more prevalent than Type-III (33.33\%),
Type-I(10.41\%), Type-V (8.33 \%), Type-VI (2.08 \%) and Type-IV (1.04 \%).

Therefore, maximum percentage of anastomoses has been documented in upper and middle sector of petals, rather than the lower sector of petals. It is evident that $100 \%$ anastomoses of the vein is concentrated in central and peripheral sectors.

Regarding the study of petal venation, low percentage of anastomoses has also been reported by Banerjee and Mukherjee (1970)from the species of Ranunculus scleratus L.

Regarding the petal venation, Chrtek (1962, 1963) had given the opinion that anastomosed venation is primitive, while Foster and Arnott (1960), Banerji (1976), Banerji and Mukherjee (1970), Subramanyam and Nair (1973) had expressed their opinion that open dichotomous vein is primitive. On the basis of these two opinion, the petal venation of $K$. pubescens, it is evident that it has an intermediate type of petal venation having both open dichotomous type as well as anastomosed type. Therefore, considering the petal venation the family Zygophyllaceae is moderately evolved family according to modern system of plant classification.

\section{Percentage of anastomoses in basal region}

Type.I $=6 / 17 \mathrm{x} 100 \%=35.2 \%$

Type.V= $3 / 17 \times 100 \%=17.6 \%$

Type.VI $=1 / 17 \times 100 \%=5.8 \%$

Type.II $=6 / 17 \mathrm{x} 100 \%=35.2 \%$

Type.III $=1 / 17 \times 100 \%=5.8 \%$

\section{Percentage of anastomoses in central region}

Type.II $=39 / 82 \mathrm{X} 100 \%=47.56 \%$

Type.VI $=3 / 82 \times 100 \%=3.65 \%$

Type. $\mathrm{IV}=4 / 82 \times 100 \%=4.8 \%$

Type.I $=14 / 82 \mathrm{X} 100 \%=17.07 \%$

Type.V $=11 / 82 \times 100 \%=13.41 \%$

Type.III $=11 / 82 \times 100 \%=13.41 \%$

\section{Percentage of anastomoses in distal region}

Type. $\mathrm{V}=8 / 96 \times 100 \%=8.33 \%$

Type.II $=43 / 96 \times 100 \%=44.7 \%$

Type.III $=32 / 96 \times 100 \%=33.33 \%$

Type.I $=10 / 96 \times 100 \%=10.41 \%$

Type.IV=1/96x100\%=1.04\%

Type.VI $=2 / 96 \times 100 \%=2.08 \%$

\section{Competing Interests:}

The authors do not have any competing interests.

\section{Author's contribution:}

This work has been totally contributed by both the authors. 


\section{Acknowledgements}

The authors are thankful to the local persons of the collected area for providing the necessary help during collection.

\section{References}

Arnott, H. J. and S. C. Tucker. 1963. Analysis of petal venation in Ranunculus I. Anastomoses in $R$. repensvpleniflorus. Amer. J. Bot. 50: 821-830. http://dx.doi.org/10.2307/2440201

Banerjee, M. L. 1972. Morphological studies on petal venation of Ranunculus diffusus DC. And its affinities with fossil materials. Biology of Land Plants, pp. 1-8, SaritaPrakashan, Meerut.

Banerjee, M. L. 1976. Petal venation of Ranunculus diffusus DC. I. Bull. Bot. Soc. Bengal. 30: 37-41.

Banerjee, M. L. and M. Mukherjee. 1970. Petal venation in Ranunculus scleratus L. Castanea. 35: 157-161.

Bennet, S. S. R. 1979. Flora of Howrah District (West Bengal). International Book Distributors, Dehra Dun.

Chartek, J. 1963. Die Nervatur der Kronblatterbei den Vertretern der Ordnung Rosales s.l. Acta. Horti. Bot. Pragensis. Pp. 12-29.

Chrtek, J. 1962. Der Verlauf der Nervatur in den Kronblatternbzw. Kronen der Dicotyledon. Novitates Bot. Horti. Bot. Univ. Carolineaea Pragensis. Pp-3-10.

Datta, P. C. and N. Saha. 1968. Specificity of distribution of venation anastomosis patterns in petals of Phaseoleae (Leguminosae). Ann. Bot. 22: 791-861.

Foster, A. S. 1966. Morphology of anastomosis in the dichotomous venation of Circaeaster. Amer. J. Bot. 53: 588-599. http://dx.doi.org/10.2307/2440009

Foster, A. S. 1968. Further morphological studies on anastomosis in the dichotomous venation of Circaeaster. J. Arnold Arb. 49: 52-57.

Foster, A. S. 1971. Additional studies on the morphology of blind vein-endings in the leaf of Circaeaster agrestis. Amer J. Bot. 58: 263-272. http://dx.doi.org/10.2307/2441163

Foster, A. S. and H. J. Arnott. 1960. Morphology and dichotomous vasculature of the leaf of Kingdoniauniflora. Amer. J. Bot. 75: 684-698. http://dx.doi.org/10.2307/2439520

GuhaBakshi, D. J. N. 1984. Flora of Murshidabad District, West Bengal, India. Scientific Publishers.

Gupta, M. 1982. Petal venetion in Trigonella (Papilionaceae). Proc. Indian Acad.Sci. (Plant Sci.) 91 (5): 379-388.

Hooker, J. D. (1875-1897). Flora of British India. (Volume1-7). L. Reeve \& Co. Ltd. London. Reprinted, Botanical Survey of India, Calcutta, 1961.

Jana, B. K., Saha, S. and S. K. Mukherjee. 2013. A comparative study of petal venation between Brassicanigraand Brassicacamprestris. Advance Research in Pharmacuticals and Biologicals. 3(2): 1-5.

Jana, B. K. and S. K. Mukherjee. 2013. Study of petal venation in Ranunculus laetus of the family Ranunculaceae. International Journal of Chemical and Pharmaceutical Research. 2(10): 316-320.

Mabberley, D. J. 2008. Mabberley's Plant Book. Third Edition. Cambridge University Press, UK.
Melvillee, R. 1969. Leaf venation pattern and origin of the Angiosperms. Nature, Land. 224: 121-125.

I. Mitra, S. AND S. K. MUKHERJEE. 2013. FLORA AND ETHNOBOTANY OF WEST DINAJPUR DISTRICT, WEST BENGAL. BISHEN SingH \& MAHENDRA PAL Singh, DEHRA DUN, INDIA.

Prain, D. 1903. Bengal Plants. Volume I \& II (Rep. Ed., 1963), B. S. I., Calcutta.

Saynal, M. N. 1994. Flora of Bankura District. Bishen Singh \&Mahendra Pal Singh, Dehra Dun, India.

Subramanyam, K. and N.C. Nair. 1973. Dichotomous venation and anastomosis in corolla of an Orchid. Proc. Indian Acad. Sci. (Plant Sci.).78: 195-202. 